\title{
UNNAMED INTERESTS AND INFORMAL LEADERS: A STREET VENDOR RELOCATION IN YOGYAKARTA CITY
}

\section{Sheri L. Gibbings ${ }^{1}$}

On a warm spring evening in 2007, I sat on a bench with "Arif," a street vendor, discussing the municipal government's plan to relocate three groups of vendors to a marketplace. He explained that the government's relocation plan had raised questions and suspicions among a group of traders who identified themselves as Pethikbumi (Paguyuban Pedagang Klithikan Mangkubumi). In their opinion, the municipal government was trying to impose this relocation onto the street vendors in an undemocratic manner. Furthermore, the government was misrepresenting the situation in order to further its own political ends. The municipal government claimed that the traders being relocated were secondhand-goods (klithikan) and antiques traders. However, while this was true for some of the groups of vendors involved, the majority of the traders selling on Mangkubumi Street sold new merchandise. From Arif's viewpoint, the mayor, Herry Zudianto, was behind this project. Arif said,

Because Yogyakarta is famous for its tourism, [Herry] wants to build a specialized market for antiques and second-hand goods. Because Herry is the

\footnotetext{
${ }^{1}$ I am grateful to my informants who shared their knowledge and experiences with me during my fieldwork in Yogyakarta. The Wenner Gren Foundation and the Social Sciences and Humanities Research Council of Canada (SSHRC) made this research possible. I thank Joshua Barker, Katherine MacIvor, and the two anonymous reviewers for their critical comments on earlier drafts. I also thank Indonesia's editors for their comments. Any remaining errors are my own.
} 
boss [bosnya] of Yogyakarta City, we suddenly became a group selling antiques and klithikan. In Indonesia, even if those above receive a different report from below, what is important is "the boss is happy" (ABS or Asal Bapak Senang). Herry knew on the ground [from low-level government officials] that only a few people sold antique or second-hand merchandise. The idea of Herry, however, as a businessperson, was to make this special antique market because the prospects would be good. ${ }^{2}$

Arif was skeptical that substantial political changes had taken place in Indonesia since reformasi. He was angry about what he considered the street vendors' inadequate level of participation in the planning of the relocation project, and he spent much of our conversation describing why this project was unjust. At the same time, Arif noted that the political landscape of Yogyakarta had changed. A legal aid organization and a student activists' group were helping to support Pethikbumi in its opposition to the relocation. The traders, with the support of these organizations, were able to protest, engage with the mass media, and use this relocation project to call for improved government transparency and accountability.

Since Suharto was ousted in 1998, the urban political environment has been affected by the implementation of new democratic and decentralization policies and the influx of private capital. ${ }^{3}$ Important aspects of this shift in state power are illuminated through examining transformations to informal leadership in the urban environment. With the collapse of the New Order, a new series of figures has emerged. ${ }^{4}$ Joshua Barker has described three different generations of informal leaders at the neighborhood level in Bandung. The first generation headed football and wrestling clubs, had strong connections with the army, and hired out thugs to businessmen. The second generation, although still leaders in their own right, based their prominence on past achievements. The final generation had a very different style. These leaders gained recognition from organizing informal sector workers, such as street traders. Barker says, " ... a different kind of leader has emerged-still informal, but less tough, more entrepreneurial, and more political. ${ }^{5}$ In the multiparty system, this new type of neighborhood leader claims to mobilize the masses for political purposes. $^{6}$

The focus of this paper is the role of the mayor and informal leaders at the city level during a government-organized street vendor relocation project that took place in late 2007, which moved three groups of traders in Yogyakarta City from downtown streets to an enclosed marketplace. In this context, informal leaders are understood to be

\footnotetext{
${ }^{2}$ Arif, interview with the author, April 2007, Yogyakarta.

${ }^{3}$ Robbie Peters, "The Wheels of Misfortune: The Street and Cycles of Displacement in Surabaya, Indonesia," Journal of Contemporary Asia 40,4 (2010): 568-88.

${ }^{4}$ Joshua Barker and Johan Lindquist, with Tom Boellstorff, Chris Brown, Aryo Danusiri, Dadi Darmadi, Sheri Gibbings, Jesse Grayman, James Hoesterey, Carla Jones, Doreen Lee, Daromir Rudnyckyj, Rachel Silvey, and Karen Strassler, "Figures of Indonesian Modernity," Indonesia 87 (A pril 2009): 56.

${ }^{5}$ Joshua Barker, "Negara Beling: Street-Level Authority in an Indonesian Slum," in State of Authority: The State in Society in Indonesia, ed. Gerry Van Klinken and Joshua Barker (Ithaca, NY: Cornell Southeast Asia Program Publications, 2009), p. 49.

${ }^{6}$ Ibid., p. 72.
} 
individuals who are not elected to office or working as civil servants, yet who hold significant authority in the city. Despite not working for the government, these informal leaders are not entirely separate from the state. In many cases, the state has been active in shaping the forms of informal authority that exist in the city. ${ }^{7}$ Although there were leaders among the street vendors during the lead-up to the relocation, another set of informal leaders, who were not street vendors themselves, appeared to help facilitate the relocation (or its opposition). These leaders had more experience organizing protests, contacting political parties, and filing lawsuits, and gained their authority from knowing how to navigate social and political channels in the city.

The informal leaders involved in this street vendor relocation varied significantly in their styles, goals, and methods. They can be categorized into at least three different types. ${ }^{8}$ The first type is the professional human-rights advocate who seeks to influence change in the city through formal and legal channels while using the discourses of human rights and democracy. These professional types, who claimed they had "no interests" and were purists trying to uphold democratic principles, ironically elicited the most suspicion. The second type is the "tough guy," and his status is based on his large number of followers, his spiritual qualities, and his ability to control populations through both the use and inhibition of violence. People were not suspicious of this type because his interests could be traced clearly to his political contingency (in this case, a particular ethnic group). The third type is an individual who operates through any channel necessary-whether formal, legal, or otherwise-in order to succeed. This type includes professional, educated individuals who are also willing to use intimidation or violence. These overtly political actors, who actively accept and distribute money from the government, attract less suspicion than the "purists" because their interests are named. In the case of this relocation project, the mayor, as a formal leader, found himself having to compete with these informal leaders for the support of the traders. As a result, he chose and displayed a leadership style that highlighted his capacity to listen to and "dialogue" with the traders, even while he was forging ahead with the relocation project-without considering the possibility of re-ordering the street as the Pethikbumi traders had requested.

I examine the biographies of individuals who embody these three types of informal leaders as well as their involvement in the relocation project in order to reveal the variation in how they related to traders and state officials, as well as the significant overlap in their styles. This case study illustrates how the new types of leaders who have emerged, including the more professional leaders and those who are a hybrid of tough and professional, are differentiating themselves from the traditional "tough guy" leaders. ${ }^{9}$ Furthermore, in the absence of a state monopoly of power, the mayor must present himself as a new kind of formal leader who "listens" to the people in order to compete with the informal leaders for the support of traders.

\footnotetext{
${ }^{7}$ Ibid., p. 71.

${ }^{8}$ In Joshua Barker's essay "Negara Beling," he places the informal leaders into different types according to generation. In this essay, I am placing them into different types based upon their methods of engagement in relation to this street vendor relocation. It would be possible to organize and describe these informal leaders according to their respective generations as well.

${ }^{9}$ See Barker, "Negara Beling," p. 49.
} 
The proliferation of different individuals and groups involved in the street vendor relocation suggests that democracy and decentralization have given rise to a diverse range of political intermediaries, some of whom undermine state power while others consolidate it. ${ }^{10}$ The municipal government appears to have less of a monopoly over informal groups since reformasi than it had previously, and new and different informal leaders are competing for these informal constituencies. As a result, groups such as street vendors have greater bargaining power vis-à-vis their patrons," while at the same time there is suspicion of new groups that seek to organize in ways other than the typical patron-client relationship.

\section{Informal Leaders in Context: Suspicion and Rumors}

In Indonesia, democratization and decentralization have meant that municipal governments have more economic and political power than during the New Order era (1966-98). There has been a transfer of administrative and political authority to the lower levels of government, and municipalities are responsible for a wide range of new administrative tasks. ${ }^{12}$ Reformasi has given rise to a growing number of NGOs and human rights organizations in Yogyakarta City, whose work often-but not alwaysaligns with the desire of the government to control and formalize street traders. ${ }^{13}$ The result is that new leaders who are capable of mobilizing street traders-for or against the government-have gained prominence in the city. In this new context, moreover, the mayor has found himself having to compete for the loyalty of traders with the informal leaders who oppose his plans. Democratization has brought more and different types of actors into city politics to an extent never seen before.

Informal leaders operating in the city have emerged out of a unique political context. Suharto's thirty-one years of rule relied on "dimly lit operations of organized terror." ${ }^{14}$ Suspicion and fear were commonplace during this period, as appearances suggested another reality was being concealed. ${ }^{15}$ Distrust and terror became so engrained that they have persisted, even since Suharto's resignation. Conspiracy theorizing is a form of "sensible" political communication in Indonesia, according to Nils Bubandt. He argues that it is "an understandable reaction to three decades of New

${ }^{10}$ This is similar to what Ian Wilson has found with regard to organized gangs, vigilantes, and militias in Indonesia. Ian Wilson, "Testing the Boundaries of the State: Gangs, Militias, Vigilantes, and Violent Entrepreneurs in Southeast Asia," in Routledge Handbook of Southeast Asian Politics, ed. Richard Robison (London: Routledge, 2012), p. 289.

${ }^{11}$ Simandjuntak has argued that "patronage democracy" in Indonesia has given clients more power vis-àvis their patrons. Deasy Simandjuntak, "Gifts and Promises: Patronage Democracy in a Decentralised Indonesia," European Journal of East Asian Studies 11 (2012): 99-126. See also Peters, "The Wheels of Misfortune," pp. 568-88.

${ }^{12}$ Henk Schulte Nordholt, "Decentralization and Democracy in Indonesia: Strengthening Citizenship or Regional Elites?" in Routledge Handbook of Southeast Asian Politics, ed. Richard Robison, p. 230.

${ }^{13} \mathrm{My}$ work is indebted to Joshua Barker, who has noted that the prominence of new leaders is related to the growing importance of the street economy in Cicadas. Barker, "Negara Beling," p. 49.

${ }^{14}$ Karen Strassler, "Gendered Visibilities and the Dream of Transparency: The Chinese-Indonesian Rape Debate in Post-Suharto Indonesia," Gender and History 16,3 (2004): 69.

${ }^{15}$ Benedict Anderson, "The Languages of Indonesian Politics," in Language and Power: Exploring Political Culture in Indonesia (Ithaca, NY: Cornell University Press, 1990), pp. 123-51, esp. p. 150. 
Order state terrorism and rampant reformasi thug rule (premanism)." ${ }^{16}$ Paranoia was both a "form of political critique" and a "standard political practice." ${ }^{17}$ In the reformasi period, political action continues to take place within "discourses of political paranoia." ${ }^{18}$ In particular, there remains no clear boundary between unofficial discourses, such as rumors, and more official discourses. In his study of pamphlets, Bubandt argues, "straddling the line between official document, forgery, and rumor, political pamphlets attest to the inseparability of unofficial and official discourse in politics, certainly in Indonesian politics." ${ }^{19}$

During my fieldwork, I found that individuals continued to be suspicious of various actors, and they confided that there remains an off-stage realm of politics. For instance, many of the traders expressed the opinion that while the mayor appeared to be engaging in democratic debate and diplomacy, in fact he had created a horizontal conflict among the traders in order to weaken the power of their group. Rumors circulated about plans to kidnap the street vendor leaders. ${ }^{20}$ In March 2007, the traders in a meeting described how preman (thugs) were being used to intimidate them. In the meeting, one street vendor said:

It turns out that government projects themselves use a kind of violence, and this was proven when we were demonstrating in the entrance to the municipal government [building]. There was the gathering of preman wearing black uniforms, around forty people. And it turned out it was being coordinated by him [the mayor], and he dispersed them [... ${ }^{21}$

During protests, the leaders of Pethikbumi watched for both intelligence operatives and preman. They were paranoid about who might be listening to their conversations or taking photos on the street, and what might happen to them. One leader of Pethikbumi regularly told stories about how government officials were threatening to label him a provokator and blacklist him. Other leaders also participated in discussions about how traitors and enemies were embedded within their own organization. This relocation project generated a mild form of what Patricia Spyer calls "hyperhermeneutics," demonstrated by people's inclination to distrust appearances and search for hidden meanings and messages. ${ }^{22}$

In the context of this mild "hyper-hermeneutics," certain types of informal leaders who claimed they had no political interests were susceptible to distrust from the traders and other leaders. In particular, since they were not channeling a visible flow of money and material goods, these leaders became vulnerable to charges that they were operating "behind the screen" or that they were paid agents of unnamed interests.

\footnotetext{
${ }^{16}$ Nils Bubandt, "Rumors, Pamphlets, and the Politics of Paranoia in Indonesia," The Journal of Asian Studies 67,3 (2008): 810 .

${ }^{17}$ Ibid.

${ }^{18}$ Ibid.

${ }^{19}$ Ibid., p. 793.

${ }^{20}$ A report was made to the police on the threat of kidnappings and was recorded on Saturday, April 14, 2007, at 21:30. "Kronologis Intimidasi Terhadap Pengurus Pethikbumi."

${ }^{21}$ Municipal government meeting, July 5, 2007, Yogyakarta.

${ }^{22}$ Patricia Spyer, "Fire without Smoke and Other Phantoms of Ambon's Violence: Media Effects, Agency, and the Work of the Imagination," Indonesia 74 (2002): 21-36.
} 
These informal leaders' claim of having "no interests" (tidak ada kepentingan) must be situated in the political imaginary of the New Order. During that era, common figures-the provokator (agitator), the dalang (puppeteer), and the pihak tertentu ("certain segment")—were assumed to be provoking conflict or interfering with politics, but they were unnamed, shadowy actors. ${ }^{23}$ "Organizations without form" (organisasi tanpa bentuk, or OTB), were also blamed for planning to destabilize the government. ${ }^{24}$ The idea of having no interests today is likened to having "unnamed interests," a common label used by the New Order government to suggest that certain persons had connections with communism. Although the informal leaders of the 2007 street vendor relocation tried to present themselves in opposition to the agitator or puppeteer, as democratic actors, they were haunted by the political imaginary of the past. Their claim to be operating without interests suggested possible opacity, unnamed interests, and conspiratorial realities. ${ }^{25}$

Rumors are representative of current social and political conditions in an urban environment. ${ }^{26}$ In particular, Karen Kroeger argues that rumors express concerns about the breakdown of social order. ${ }^{27}$ She describes how the AIDS Club rumors in Surabaya occurred in middle-class spaces such as shopping malls, movie theaters, game rooms, and discotheques. These spaces "embody the ambivalence" that Indonesians felt about the changes in the urban landscape, such as the growing gap between the wealthy and the poor and the breakdown of moral values. ${ }^{28}$ Lisa Butt argues that conspiracy theories regarding AIDS in Papua were a response to the national government's unpredictable, mysterious, and inconsistent methods of regulating sex workers and AIDS. In other words, Papuans built conspiracy theories because there were "inconsistencies" and "disjunctures" in the way AIDS cases were handled. ${ }^{29}$ In this paper, I argue that the rumors surrounding the relocation project were related to concerns about the changing order of urban politics and, in particular, the role of new types of groups and leaders. The traders and their leaders used conspiracy theories to map the new political landscape in the city, and to make sense of what appeared as a disjuncture between the old Suharto-era techniques of intimidation and violence and new practices of "democracy" in Yogyakarta.

Urban Indonesians often view officials-whether at the national, regional, or municipal level—as part of a murky, manipulative, shadowy government. James Siegel has described how, during the New Order, rumor was problematic when the source was not believed to be the government. He writes, "This is a politics of origins where

\footnotetext{
${ }^{23}$ Joshua Barker, "State of Fear: Controlling the Criminal Contagion in Suharto's New Order," in Violence and the State in Suharto's Indonesia, ed. Benedict R. O'G. Anderson (Ithaca, NY: Cornell Southeast Asia Program Publications, 2001), pp. 20-53.

${ }^{24}$ James T. Siegel, A New Criminal Type in Jakarta (Durham, NC: Duke University Press, 1998), pp. 5-6.

${ }^{25}$ Harry G. West and Todd Sanders, Transparency and Conspiracy: Ethnographies of Suspicion in the New World Order (Durham, NC: Duke University Press, 2003).

${ }^{26}$ Karen A. Kroeger, "AIDS Rumors, Imaginary Enemies, and the Body Politic in Indonesia," American Ethnologist 30,2 (2003): 243.

${ }^{27}$ Ibid.

${ }^{2 s}$ Ibid., p. 249.

${ }^{29}$ Lisa Butt, "'Lipstick Girls and 'Fallen Women': AIDS and Conspiratorial Thinking in Papua, Indonesia," Cultural Anthropology 20 (2005): 414.
} 
the point of forgeries is not to convince anyone of the truth of their contents but to make them believe that all rumors, accurate or not, favorable or not, have their starting point in the government." ${ }^{30}$ Karen Kroeger likewise describes how the municipal government positioned itself as the source of rumor in Surabaya in order to "maintain the upper hand." ${ }^{31}$ In the newspaper, the municipal government blamed the AIDS Club rumors on "imaginary enemies." Kroeger concludes, "This served to arouse the suspicion of those who might appear to undermine the nation and reestablished the moral authority of the government as the protector of the public good. ${ }^{\prime 2}$ In the case I describe here, the municipal government likewise circulated a rumor in the newspaper that the pro-democracy group had unnamed interests. Rumors had circulated among the various actors as they accused each other of having unnamed interests in the months prior, but the municipal government eventually became the official source of this rumor.

\section{Patron-Client Relations and the City}

Clifford Geertz, discussing postcolonial Indonesia, described social and political life as organized in currents or streams (aliran). In this mode, networks of informal mass organizations were related to political parties, and it was through these informal relations that people could gain access to permits, loans, or other necessities. ${ }^{33}$ The New Order has been described as an era of centralization during which political life was organized tightly around "the state," and political associations that wanted to play a role were forced to associate with the state. ${ }^{34}$ Whether associated with "political aliran" immediately after independence or with state agencies during the New Order, members of the informal economy in Indonesia have historically relied on political intermediaries to safeguard their livelihoods. ${ }^{35}$

Research has described how, during the New Order, street vendors paid off municipal officials, the military, or thugs (associated with the state) in return for protection. T. G. McGee and Y. M. Yeung, describing one trader in Jakarta in the 1970s, have written, "He says that he pays a licence fee (the amount is not specified) to an individual who says he is from the Municipality. But the administration regards him as unlicenced and claims no knowledge of the licence-collecting officials." ${ }^{36}$ Likewise, Lea Jellinek, also in the 1970s, has described how traders in Jakarta relied on army contacts

\footnotetext{
${ }^{30}$ James Siegel, “I Was Not There, But ...” Archipel 46 (1993): 64.

${ }^{31}$ Kroeger, "AIDS Rumors," pp. 251-52.

${ }^{32}$ Ibid., p. 252.

${ }^{33}$ Clifford Geertz, Peddlers and Princes (Chicago, IL: University of Chicago Press, 1963), pp. 14-15.

${ }^{34}$ Edward Aspinall, "A Nation in Fragments: Patronage and Neoliberalism in Contemporary Indonesia," Critical Asian Studies 45,1 (2013): 32-33.

${ }^{35}$ Lea Jellinek, The Wheel of Fortune: The History of a Poor Community in Jakarta (Sydney: Asian Studies Association of Australia in Association with Allen and Unwin, 1991).

${ }^{36}$ T. G. McGee and Y. M. Yeung, "Hawkers in Southeast Asian Cities: Planning for the Bazaar Economy," International Development Research Centre (1977), p. 15.
} 
for protection from government clearing operations. ${ }^{37}$ Alison J. Murray has argued that the informal sector is based on connections to elites. She says,

The organizational hierarchy and its relations of power and authority form part of Indonesia's system of patronage and using "connections." The ruling elite invokes the patron-client model to foster an ideology of dependence, and justifies exploitation by encouraging alleyside people to think of themselves as the little people (wong kecil) who fatalistically accept that they are unenlightened (masa bodoh). Connections are popularly seen as an important resource: "connections are always above the law" (koneksi selalu atap hukum). ${ }^{38}$

During the New Order, the street vendors in Yogyakarta City primarily depended on preman, officials (such as civil servants, police, or army personnel), and ethnic networks to protect them in exchange for the payment of informal taxes. In the 1980s, a group of street traders in Yogyakarta secured their position on the street by working with Kosgoro, an organization associated with the state party, Golkar. ${ }^{39}$ These traders actively aspired to be patrons of the state by claiming to adhere to the goals of Pancasila (the state ideology), and by organizing highly visible street-cleaning events. They created an organization (Satuan Tugas Kebersihan, Ketertiban, dan Keamanan, the Cleanliness, Order, and Security Task Force) to conduct operations against their fellow traders, illustrating their commitment to upholding the state-sanctioned values of order and cleanliness. ${ }^{40}$

While some larger and more organized groups were recognized by the state in the 1990s, most street vendors continued to find protection through payment to the right officials. In 1997, the Ministry of Home Affairs (Departemen Dalam Negeri) conducted a "Study on the Constructed Participation of the Urban Informal Sector" with a focus on street vendors. The pedagang warung (food stalls or small shops) in Tegal, Jakarta, were found to be located in places that were not planned or allowed for that use by the government. The vendors unofficially paid rent to the subdistrict office for the location and for "security." In order to reserve a selling location, vendors often had to pay security money to institutional figures acting unofficially, such as members of the Indonesian National Armed Forces (TNI, Tentara Nasional Indonesia) or the Indonesian National Police (Kepolisian Negara Republik Indonesia, POLRI). Another common form of payment was to let TNI or POLRI eat for free from time to time at one's warung. ${ }^{41}$

\footnotetext{
${ }^{37}$ Lea Jellinek, The Life of a Jakarta Street Trader-Two Years Later (Melbourne: Centre of Southeast Asian Studies, Monash University, 1976), p. 10.

${ }^{3 s}$ Alison Murray, No Money, No Honey: A Study of Street Traders and Prostitution in Jakarta (Singapore: Oxford University Press, 1991), p. 24.

${ }^{39}$ Pak Dody, interview with the author, June 2007, Yogyakarta. The formation of state-associated cooperatives was one way the state was also able to contain the possible radicalism of this group.

${ }^{40}$ Bangun Amran, Sejarah Berdirinya Koperasi Tri Dharma, Persatuan Pedagang Pinggir Jalan Yogyakarta [History of the Establishment of Tri Dharma Cooperative in Yogyakarta, Roadside Traders Association] (Yogyakarta: Tri Dharma Cooperative, 1994).

${ }^{41}$ Joedo Ir. Goenadi Malang, Studi Pembinaan Peran serta Sektor Informal Perkotaan: Laporan Akhir [Study of Fostering the Participation of the Urban Informal Sector: Final Report] (Jakarta: Departemen Dalam Negeri, Direktorat Jenderal Pembangunan Daerah, Direktorat Pembinaan Pembangunan Perkotaan, 1997).
} 
The patron-client relationships that existed from the 1970s to the 1990s were based on two different types of exchanges. As in Tegal, the first kind of exchange between citizens seeking favors and individual officials such as the military, police, or thugs was based on an exchange of money, food, or goods. The second kind of exchange, with political parties or the state, was based on an exchange of political support and an adherence to Pancasila. Although unofficial payments of material goods to patrons allowed street vendors to remain on certain streets, the vendors also tried to claim their right to the street by signaling their commitment to state ideologies and thus their belonging as national subjects.

When Indonesia began the transition to democracy after 1998, constitutional amendments and administrative decentralization were instituted to shift political power to the local levels, curtailing the previous dominance of the central government in local affairs. ${ }^{42}$ Ian Wilson argues that, in the era of democratic reforms, the state has been less able to monopolize force than previously (he makes this assertion while acknowledging that this monopoly was largely a myth), and the result has been to increase the roles of various groups, such as street gangs, who have rebranded themselves. ${ }^{43}$ Wilson argues that these new gangs, militias, or paramilitaries offer opportunities for economic and social mobility to citizens disadvantaged by urbanization, poverty, and the lack of formal employment. ${ }^{44}$ Many of the gangs, although violent, contribute to the well-being of the poor, in a context where state services are not readily available. Besides the growth of gangs, ethnic militias, and vigilante groups, there are also human rights lawyers, non-governmental organizations, and student organizations that act to provide protection to groups such as street vendors. More ethnographic research is needed on the role of NGOs and other well-intentioned organizations, and how they relate to or work in different ways with groups such as street vendors. In this paper, I show that street vendors are not solely reliant on thugs for favors or patronage, and that new types of brokers are increasingly helping traders navigate the legal and institutional terrain of the city.

Edward Aspinall argues that "patronage is the most important glue of political relations in Indonesia" in the context of a changing political economy. He argues that patronage is fragmented because political connections are not built on ideology but on the exchange of political loyalty for material rewards. This allows for multiple patrons to compete with each other for clients, and for clients to choose a patron willing to offer the highest reward. ${ }^{45}$ Because there is a lack of central organizing groups (central groups were characteristic of the aliran pattern) and strong identity-based politics around which to structure the flow of patronage, he calls the conditions of this new era "decentralized clientelism." 40

As I observed in Yogyakarta City, the new politics of democracy involved the emergence of a growing number of political intermediaries who participated in

\footnotetext{
${ }^{42}$ Nankyung Choi, "Local Elections and Party Politics in Post-Reformasi Indonesia: A View from Yogyakarta," Contemporary Southeast Asia 2,2 (2004): 208.

${ }^{43}$ Wilson, "Testing the Boundaries of the State," p. 297.

44 Ibid.

${ }^{45}$ Aspinall, "A Nation in Fragments," pp. 30-31.

${ }^{46}$ Ibid., p. 36.
} 
decentralized clientelism. Rusdi, a parking agent leader and trained lawyer, described his power as a local broker because he could mobilize several thousand parking agents for a local election. Sardjito, a university-educated reformasi activist, was another member of the mayor's recent "team success." ${ }^{47}$ He had mobilized hundreds of traders on Malioboro Street during the previous election. At the time of my fieldwork, he was in the midst of organizing cigarette peddlers (asongan) into an organization and helping them secure support from a company. These members of the mayor's "team success" were all relatively new leaders who had managed to mobilize various sectors of the urban poor after 1998 not only for elections, but also for urban planning projects.

A wide range of actors have interests in street vendors and their relocation: political parties, NGOs, preman, mass organizations (Organisasi massa, Ormas), vendor groups, and the municipal government. This case study illustrates how the street vendors (both those for and against the relocation) were not initially closely tied to larger sociopolitical networks in the city, but were drawn in through informal leaders during the mounting political crisis. The emergence of these alliances suggests that such political alliances in the city are fragmented, flexible, and formulated during and through urban projects. ${ }^{48} \mathrm{~A}$ wide range of non-state actors appeared on the scene, some of whom challenged state power, while others worked to consolidate and maintain it. ${ }^{49}$ These groups provide street vendors, members of the informal economy, with a network of solidarity, and opportunities and help to address their needs in a context where they have few rights. ${ }^{50}$ In the next section, I describe the social and political background behind recent relocations in Indonesia, and how the traders became divided into two groups: "pro-relocation" and "anti-relocation." Each of these groups became involved in its own network of support with informal leaders, a process that will be described in the following section.

\section{Relocation for Remuneration: A Divided Group}

After the Asian economic crisis began in 1997, the number of street vendors in Yogyakarta increased dramatically. At the time of my research (2006-08), it was estimated that there were approximately five thousand street vendors in the city. Although the public and the municipal government were generally sympathetic to the plight of traders in the context of the economic downturn, in 2004 the government started to consider a relocation of traders from three neighborhoods ( 377 traders from Mangkubumi, 80 from Asemegede, and 113 from South Square) to a marketplace with 606 stalls. In 2007, the government tried to convince the traders that relocation to the market would be beneficial for them: they would become part of the formal economy, they could store their merchandise on site, and they could avoid harsh weather. ${ }^{51}$

\footnotetext{
${ }^{47}$ Their membership as part of this team was unofficial and not widely known across the city.

${ }^{48}$ Edward Aspinall argues that there is a trend towards fragmentation. lbid., pp. 27-54.

${ }^{49}$ Ian Wilson describes how gangs, vigilantes, and militias play different roles of either eroding or consolidating state power. Wilson, "Testing the Boundaries of the State," pp. 288-301.

${ }^{50}$ Wilson argues that some of these violent groups do provide solidarity and help to the individuals who are in economic need. Ibid., p. 299.

51 “Menuju Relokasi ke Eks Pasar Hewan Kuncen,” Kompas, June 27, 2007.
} 
The government wanted to relocate the traders for several reasons. First of all, a marketplace had recently been made available after the livestock traders that had occupied it were moved outside the city limits. Second, the public considered the growing number of traders in downtown streets to be "dirty" and the cause of chaos and traffic jams. Some of the traders targeted for this relocation sold secondhand merchandise (which was considered particularly dirty) in busy and highly visible locations. Third, shop owners, many of whom lived above their shops, complained about the difficulty of leaving or entering their homes and/or businesses due to the concentration of informal-sector vendors. ${ }^{52}$ Mayor Herry Zudianto could not ignore the growing concerns of shop owners that their "legitimate" businesses were suffering because of the illegal traders in this important commercial center of the city, and he gave the relocation his full support.

Perhaps the most important reason for the relocation, however, was the government's desire to secure revenue from the traders. An important issue in municipal politics across Indonesia recently has been the necessity to increase revenue to fund cities' growing responsibilities and powers. ${ }^{53}$ The official revenue of Yogyakarta is increasing; in 2007 it was 114,098,350,942.31 rupiah (approximately 11.9 million USD), and by 2008 it had increased to 132,431,571,541.72 rupiah (approximately 13.8 million USD). ${ }^{54}$ One way that the government has been able to increase revenue is by collecting more from individuals in the informal economy who were once considered illegal, including parking agents and street vendors, but who are now being variously recognized, legitimized, and effectively taxed.

During my fieldwork, I observed the district and subdistrict offices across Yogyakarta City work diligently to gather data on the traders in their regions, organize them into groups, and require them to obtain permits according to recent legislation passed by the municipal government. The other means to capture funds was by relocating the traders to a marketplace. In this case, the municipal government required the traders to buy a Trader Identity Card (kartu bukti pedagang, KBP) for 200,000 rupiah (approximately 20 USD). Although the traders would be exempt from paying fees for the first six months in the new marketplace, they would subsequently pay a daily tax to the government. ${ }^{55}$

From 2004 to February 2007, Pethikbumi traders debated the municipal government's relocation. Some traders supported the plan while others opposed it, but the street trader leaders generally expressed support. In February 2007, however, the organization declared its opposition to the relocation. Pethikbumi shifted its position after Joko, the group's leader, was discovered to be a fake. He was removed from his position, and the new leaders decided to oppose the relocation openly. The traders who continued to support the relocation formed a separate group called Independent.

\footnotetext{
${ }^{52}$ Ibid.

${ }^{53}$ Robbie Peters, "The Assault on Occupancy in Surabaya: Legible and Illegible Landscapes in a City of Passage," Development and Change (special edition: "Cities of Extremes") 40,5 (2009): 903-25.

${ }^{54}$ Pemerintah Kota Yogyakarta Laporan Arus Kas (Audited) untuk Tahun Yang Berakhir Per 31 Desember 2008.

55 “Menuju Relokasi ke Eks Pasar Hewan Kuncen,” Kompas, June 27, 2007.
} 
Although many traders had been hesitant about the relocation since much earlier, the vendors did not break into different factions until the controversy surrounding Joko emerged. I did not meet Joko until several months into my research, though I had heard about his role as the previous leader of Pethikbumi. According to some people, he was avoiding the street because he had been exposed and his name tarnished. He had been officially removed from the organization after he was found guilty of corruption. It was not the corruption, however, that caused the members of Pethikbumi so much distress; it was the fact that as their leader and a fellow vendor, he had advised them to support the relocation without telling them that he was also a government official, and thus stood to gain personally from the relocation. Joko was therefore disgraced, because he did not live up to the expectation that new informal leaders must be explicit about their political interests.

When the street vendors learned of Joko's hidden identity, they broke into two factions, as noted above: those who agreed to go along with the government's relocation plan (Independent) and those who opposed it (Pethikbumi). The majority of the Independent traders sold secondhand merchandise, including antiques. The majority were supportive of the relocation because they believed selling in a marketplace as opposed to on the street would increase their prestige, and give them a valuable asset for the future. In private conversations some admitted that they did not want to relocate, but felt any opposition to the government would be fruitless. They had witnessed too often the failure of movements that resisted. They believed it was a better strategy to secure a location in the new marketplace and simply return to the street later on if the project failed. ${ }^{56}$

In contrast to the Independent group, members of Pethikbumi sold mostly new items, including clothing, shoes, and hardware. They also monopolized the secondhand cell phone market in the city. This group was composed of mostly young men (between the ages of twenty and forty-five) who, over the course of five years, had converted Mangkubumi Street's small night market into a booming informal marketplace. Influenced by the democratic developments of the reformasi era, the majority hoped that they could successfully defend their right to the street rather than being forced to relocate. Members of this group also feared that moving to an enclosed marketplace would lead to financial ruin, since selling in a marketplace required more capital and involved more competition among the traders.

Once the groups were divided, differences began to surface and harden. A particular point of contention dividing the groups was their difference in incomes. Members of Pethikbumi made more than double the income of Independent group members. ${ }^{57}$ As a result, Pethikbumi members were considered greedy by the others, for

\footnotetext{
${ }^{56}$ A visit to Kuncen marketplace in 2013 revealed that many of the original secondhand traders from the Independent group had sold their locations in the marketplace and were back to selling at an outdoor marketplace called Pasar Sentir. Some traders preferred selling in an outdoor location, while others sold their kiosk in order to build a home or pay hospital fees. A significant proportion were forced to sell their kiosks after they were unable to pay back bank loans.

${ }^{57}$ The results from my research on average incomes indicated that the average income among Southern Square vendors was 34,670 rupiah, in Aseme Gede it was 82,100 rupiah, and on Mangkubumi Street it was 224,590 rupiah. The differences among the three incomes are statistically significant, with less than a 5 percent chance that this analysis is incorrect. Abidin Kusno argues that, following the economic crisis in 1997, the urban poor were "competing with the middle class in the public spaces of the city." Members of
} 
they were not just surviving off the street, they were profiting. The Independent sellers also differentiated themselves from Pethikbumi based on ethnicity. They considered Pethikbumi to be composed of mostly outsiders, from Madura, Sumatra, or elsewhere. They characterized this group as ungrateful sellers who assumed their right to the street rather than being thankful for it. They were not considered "Javanese" because they were willing boldly to refuse the government. The Independent group thus characterized their own approach as more refined and subtle, following the Javanese way of collaborating with and respecting those in power. ${ }^{58}$

Informal leaders emerged around both the Independent, pro-relocation traders, and the anti-relocation Pethikbumi traders. The pro-relocation network was supported by the mayor of Yogyakarta City, Herry Zudianto, who was from National Mandate Party (PAN, Partai Amanat Nasional) and also a local businessman. He developed the vision for the marketplace and implemented the relocation plan with the help of his "relocation team," a group of municipal government civil servants. The main informal leader supporting the mayor was Djoko, a human rights lawyer and director of an NGO. Djoko's vision was to promote democracy and human rights in Indonesia. He was connected informally to the United Development Party (PPP, Partai Persatuan Pembangunan), and helped to organize other informal leaders in the city to support the relocation. The majority of Chinese shop owners on Mangkubumi Street discreetly informed me of their support for the relocation because they faced difficulty in the evenings entering or leaving their homes (located above their shops) due to the informal street vendors who had set up stalls on the street. A few businesses open in the evenings also suffered because of the traders' presence. The shop owners feared retaliation from the traders if they voiced their support for the relocation publicly, and thus they remained silent on the issue in public forums.

The anti-relocation traders' network of supporters included the NGO Network, Indonesian Youth Movement for Change (PPIP, Pergerakan Pemuda Indonesia untuk Perubahan), and the Human Rights Protection Agency (BPHK, Badan Pelindung Hak Kemanusiaan). ${ }^{59}$ All three of these groups considered themselves part of the movement to promote democracy and human rights in Indonesia. The leader of an ethnic organization, Ahmad, also expressed his disapproval of the relocation. Looking out for the interests of the traders associated with his ethnic organization, he used the threat of violence to challenge the municipal government's position. Concerned with helping the "little people," the Indonesian Democratic Party of Struggle (PDI-P, Partai Demokrasi Indonesia-Perjuangan) and the Prosperous Justice Party (PKS, Partai Keadilan Sejahtera) each also briefly supported this group of traders. Other street trader organizations in the city disagreed with the relocation, but did not offer any substantial support to the anti-relocation traders. Besides having limited resources and time, many traders expressed a concern that opposing the relocation would put their own right to sell at risk.

the middle class were setting up restaurants or selling locations in public spaces. In this case, the traders who opposed the relocation considered themselves more educated, and in some cases more like the "middle class" than the group opposing it. Abidin Kusno, "Whither Nationalist Urbanism? Public Life in Governor Sutiyoso's Jakarta," Urban Studies 41,12 (2004): 2382.

${ }^{58}$ Benedict Anderson, Language and Power, pp. 50-54.

${ }^{59}$ All of these organizational names are pseudonyms. 
In what follows, I present the results of participant-observation and interviews with the different kinds of informal leaders involved in the relocation. The first type represents the newly emerging "democratic" brokers who present themselves as educated professionals who are knowledgeable about the law and the proper channels for engaging in advocacy. BPHK, the NGO Network, and PPIP, all of which supported the anti-relocation traders, embody this type. The second type, the traditional tough guy, can be seen in Ahmad, the ethnic organization leader who also supported the anti-relocation traders. The third and final type of informal leader, who typically displays a mix of professional/educated and tough guy traits, is seen in Djoko, a human rights lawyer. Though a professional human rights advocate, he simultaneously drew on official and informal or illegal channels to achieve his goals. Ironically, in this urban post-Suharto setting, political actors who openly accept and distribute money from the municipal government attract less suspicion than NGOs or other actors who claim to have no personal interests.

In order to compete with these new informal leaders, Mayor Herry Zudianto emulated the much beloved Sukarno, Indonesia's first president, by presenting himself as a caring father figure and claiming to listen to the traders ${ }^{\prime}$ aspirations. The general lack of faith in the government among street vendors led Herry to present himself as an accessible leader, speaking the language of traders, treating them as kin, and interacting with them in their own environment in order to gain their support.

\section{Unnamed Interests: The Professional Leaders}

When the Pethikbumi traders learned that Joko, their leader, was actually a government official, they came to the office of the human rights protection agency, $\mathrm{BPHK}$, to ask for help. They wanted to know how to get rid of Joko legally. From that point on, the organization provided them with free legal advice. Marini, the director of BPHK, was born in Medan, North Sumatra, in 1980. She went to law school in Yogyakarta and helped found BPHK in $1999 .{ }^{60}$ The founders had all met at SKHAPI (Sekolah Konsultan Hukum dan Advokat, Consultant School of Rights and Advocacy), and had been involved in student organizing during reformasi. Having helped students detained by the government during the early reform period, the goal of BPHK was to provide legal assistance to the poor and marginalized sectors of society for free. "We created BPHK to support the marginalized who have trouble obtaining a lawyer, because they do not have enough money," Marini clarified. ${ }^{61}$

Since 2002, BPHK had worked with fifteen street vendor organizations across the city to help them counter a proposed draft of legislation that would require street vendors to undertake an elaborate process to obtain a permit to sell. With the help of the traders, BPHK drafted a piece of counter-legislation and advocated for vendor organizations to be involved in the process of drafting and discussion. Around that time, BPHK also became known for supporting groups of traders who were facing eviction.

\footnotetext{
${ }^{60}$ Three of the lawyers had studied at Universitas Gadjah Mada and two at the University of Janabadra.

${ }^{61}$ Marini, interview with the author, July 16, 2013, Yogyakarta.
} 
Since Pethikbumi had asked for their help, weekly meetings were held at the BPHK office. Over the course of the relocation, BPHK helped the street vendors sketch legal letters requesting that an investigation into this relocation project be conducted by the legislative branch of the local government (Dewan Perwakilan Rakyat Daerah) because of the government's lack of transparency and communication with the traders who opposed the relocation. With the help of BPHK, five of the street vendors filed a lawsuit against the government for drafting a regulation that banned them from selling on the street without first consulting them (Regulation No. 45, 2007). According to Marini, street vendor relocations always involved many different "interests." She said, "Street vendors are sometimes viewed as objects of certain interests (kepentingankepentingan tertentu). It is the reason we remain concerned with the street vendors. But we are not producing any type of program. We are helping to support street vendors to facilitate themselves so they are not seen as just being sold." ${ }^{62}$

Marini helped the traders navigate formal bureaucratic and legal channels, but she considered their legal advocacy efforts to be limited because, according to her, the traders had trouble maintaining unity. In an interview, Marini described how it was difficult to talk about idealism with traders when they were so concerned about their daily livelihoods. She said, "Often the unity is lost during a relocation, and the government uses this as a weapon to divide the group so they don't become consolidated." ${ }^{63}$ Marini considered it common for street vendor groups to end up surrendering to the government's plan.

BPHK received funding from their wealthier clients and from international organizations. The tariff they charged their more wealthy clients was used to pay for the other activities of their office. They also used the program funding from international bodies to fund the general work of the office. Marini said, "We have never opened this up to the public because the opinion continues to be that, if we work with the international world, it is an international intervention." ${ }^{64}$ Marini did not see it that way, however. BPHK worked together with international organizations on a small number of projects, but that was it. People were suspicious of them, however, because of their "international connections."

Besides legal support, BPHK also provided Pethikbumi with a connection to a much larger network of organizations called the NGO Network, which had formed in 1986 under the careful control of the government, but had expanded since reformasi into a coordinating body with over eighty-two member organizations. ${ }^{65}$ After working with Pethikbumi for many months, Marini invited the leader of the NGO Network, Toni, to attend meetings at BPHK. Toni often facilitated the discussions at meetings, helping Pethikbumi formulate strategies for their opposition while trying to model a

\footnotetext{
${ }^{62}$ Ibid.

${ }^{63}$ Marini, interview with the author, December 12, 2007, Yogyakarta.

${ }^{64}$ Marini, interview with the author, July 16, 2013, Yogyakarta.

${ }^{65}$ The NGO Network was created in 1986 in a meeting in Semarang organized by the city government and the Danarta Ancient Foundation. The eleven NGOs that attended the meeting were invited by the city government in Central Java to create a forum of NGOs, which would be highly regulated and monitored by the government. The initial goals of the for um were to share information and experiences among the NGOs and to promote collaborative work. The members also wanted to obtain information about government plans and policies on rural and urban development.
} 
democratic forum for decision-making. Informed by his experience with other oppositional groups, Toni was able to discuss strategies that had worked or failed for other groups in the past.

Toni, of Chinese-descent himself, was thirty-one years old in 2007 and the leader of the NGO Network from 2006 to 2008 . He was the twelfth of thirteen children in his family. Unlike most of his siblings, who had undergraduate and post-graduate degrees, Toni's work with activists had made him skeptical of the education system. $\mathrm{He}$ attended university in Bandung and Yogyakarta but never graduated, preferring to learn outside of an institutionalized environment. Toni's father worked for the military and was a member of parliament for Golkar during the New Order era. During that time, few activists organized because of the threat of intimidation. Because his father worked for the military, Toni was one of the few activists who were protected from government action during the Suharto era. ${ }^{66}$

Toni said he had no proof about why this relocation project surfaced at first, but he suspected that Chinese businessmen were behind it because Herry Zudianto had been backed by the Chinese businesses when he was running for mayor. According to Toni, "we can make sense that the Chinese businesses are extraordinary in comparison with the local people. Herry was helped by the Chinese businesses when he was running for mayor, and now that they wanted these traders relocated he had to help them. ${ }^{\prime 67}$

Toni, like Marini, thought the municipal government deployed a divide-and-rule strategy to control the traders. He described how, typically, the government stretched out the advocacy and communication process to reduce the strength and finances of the traders. Once the traders had been weakened, the negotiations would start. As a result, Toni was not troubled that he was working to support the relatively more successful, prosperous vendors against the pro-relocation alliance that included the poorer vendors. Toni did not consider the anti-relocation traders to be opposed to the pro-relocation traders. Instead, from his perspective, the anti-relocation traders were against the municipal government's undemocratic process, and Toni and his allies would support any number of vendors who opposed this relocation, even if the numbers were small. Both Marini and Toni blamed the municipal government for causing the division between the traders. For them, it was a conscious government strategy to render the traders weak and less effective in their organizing.

The political culture in Yogyakarta City, for Toni, was feudal. Advocacy always failed, in his opinion, because the culture was not dynamic as in Papua or Timor Leste. There was a general lack of militancy around advocacy. He explained,

[The traders] are not psychologically ready for it. But there is spirit and support to refuse. But if we give stress or pressure, it will not be maximal. They are not going to be willing to fight as far as we imagine. They have the ability to do it, but the probability that it will happen is very small. From the mental side of things, the street vendors are not able to go there. ${ }^{68}$

\footnotetext{
${ }^{66}$ Toni, interview with the author, September 19, 2007, Yogyakarta.

${ }^{67}$ Ibid.

${ }^{68}$ Ibid.
} 
Similar to Marini, Toni found the street vendors lacked a willingness to fight the municipal government, especially when they could no longer sell on the street, had no income, and faced possible violence. ${ }^{69}$

Toni was widely connected in the activist world and beyond, and he helped the leaders of Pethikbumi to organize and strategize around their refusal of the government relocation. He was able to call the leader of the Dewan to organize meetings and analyze the current status of the Dewan with regard to the relocation. Although Toni did not have direct or permanent connections to any particular political party, he was able to call upon individuals from them and organize meetings. In an interview with me, he discussed the struggle he faced in helping groups such as street vendors. He wanted to help direct them and guide them but was always wary of acting too assertively on their behalf. He explained that he could have easily contacted the mayor directly and requested a meeting, but that he wanted to go through the formal channels. He explained the role that NGOs had played in the past:

In a history of a number of cases, the NGOs did the bargaining. But the community must also be able to do this directly. If the NGOs are always doing this, then the community will never do it. We could easily call PDI, PKS, PPP, but the process will just continue, lobbying and those who enter the bargaining position will always be the NGOs. [...] I could phone the leader of the DPRD [Dewan Perwakilan Rakyat Daerah, local parliament] to communicate our desires. But this is not fair, because this is not in the interests of the NGOs, but the interests of the street traders. The NGO Network has discussed this and has decided that they will support [the anti-relocation vendors] but try not to get too involved in the process.

Toni was representative of this new type of leader in the city who wanted to resist the government without deploying the hierarchical patronage of the New Order. Although Toni wanted to avoid being a patron, his treatment of the street vendors as children who needed to learn to advocate on their own behalf sometimes came across as condescending. He continued to describe their position:

Up until now we spoil the community. So we must start conditioning [the community] in a different way. We will start a process of making the street vendors independent [kemandirian]. They can advocate for themselves. We as the NGOs will do the monitoring or we will help at the level of litigation. ${ }^{70}$

Toni was easily able to mobilize media outlets and organize press conferences by setting up meetings between the vendors and the press and helping to draft press releases. A month before the relocation was scheduled, the NGO Network helped the street vendors organize a media event in which they spoke about the times they had been intimidated by preman on the street. The NGO Network helped the street vendors frame the issue in a way that called attention to this intimidation and suggested that

\footnotetext{
${ }^{69}$ In a local newspaper, Merapi, the NGO Network published a statement asking the mayor not to use violence against the street traders when they reached the deadline after which they were expected to abandon the street and no longer sell in that location. "Pedagang Lolos Verifikasi," Merapi, November 9, 2007.

${ }^{70}$ Toni, interview with the author, September 19, 2007, Yogyakarta.
} 
the government was behind it without making a direct accusation. ${ }^{7 /}$ Toni recognized that he was, in some sense, a patron of the street vendors, helping them navigate the bureaucratic and media worlds, but he was somewhat uncomfortable with this position. He wanted to provide the street vendors with the knowledge and skills to organize and make connections with officials themselves so they would not be dependent on him. He avoided speaking in the media too often on behalf of the street vendors and instead encouraged them to speak for themselves.

Although Toni and Marini were careful not to speak for the traders, they did expect the traders to frame the issues according to the principles of democracy and transparency. When the traders talked of organizing thugs, using intimidation, or forcing their members to hand over their membership cards in order to ensure that they remained loyal, Toni and Marini were quick to lecture them about the illegality of these practices. Toni said in an interview, "If we are threatened or terrorized, yes we should report to the police. We aren't true, however, if we are terrorized and then report to the preman or use other channels." ${ }^{72}$

Marini and Toni, representing the first type of informal leadership, had a similar outlook and were interested in organizing and helping the traders to become more democratic. Both were ready to challenge the government through the legal channels recently made available since reformasi. Both had achieved recognition in the city by virtue of their ability to fight the government using formal mechanisms. As representatives of a new generation, they were also very aware of the critiques targeted at NGOs for reproducing typical power relations among themselves, as members of the more elite, educated middle class, and the traders. They tried to avoid reproducing this hierarchy, but it proved difficult when the traders did not take up the democratic discourse that these informal leaders desired.

Although skeptical of its interests, Toni and Marini welcomed the support of the PDI-P and its overt opposition to the relocation plan. Toni and Marini, as well as the traders, had no idea that PDI-P planned to support them until a newspaper article appeared. On October 23, 2007, the PDI-P openly expressed its support for the antirelocation faction of street vendors in the newspaper. PDI-P did not mention the NGO Network or BPHK in the article. The leader of PDI-P claimed that they disagreed with the relocation because they believed that the street vendors were already successful in creating their own market on the street. He recommended that the new marketplace be used for other secondhand sellers who wanted to relocate. Instead of forcing the Mangkubumi street vendors to move, PDI-P suggested that the street vendors be spatially rearranged in consideration of the interests of shop owners and pedestrians and that they pay taxes to the government. The party also recommended that the parking areas be reorganized to prevent traffic jams. PDI-P argued that Mangkubumi could be turned into a tourist attraction, with cultural performances and pedestrian space, and the street vendors could be incorporated into this vision rather than forced out.

\footnotetext{
${ }^{71}$ Sheri Gibbings, "Unseen Powers and Democratic Detectives: Street Vendors in an Indonesian City," City E Society 25,2 (2013): 235-59.

${ }^{72}$ Toni, interview with the author, December 3, 2007, Yogyakarta.
} 
After the article was released, the traders and BPHK decided they should organize a meeting with PDI-P to discuss its support further. On October 26,2007, the leaders of Pethikbumi went to PDI-P's office. In the meeting, the leaders of Pethikbumi thanked PDI-P for its support. The leaders then described the premanism (gangsterism) that they faced on the street and how they did not feel safe. In response, PDI-P agreed to pressure the government to remove the recent regulation (Perda 45) that made selling on the street illegal. PDI-P would also push for renovating the street rather than relocating the traders. Finally, the representatives of PDI-P declared that they had a plan to ensure the municipal government would not be repressive and that they would "back them," meaning the traders.

Shortly after this meeting, one of the leaders of PDI-P visited Mangkubumi Street at ten $o^{\prime}$ clock at night. Driving up in a car and dressed in a batik dress shirt, this individual was immediately visible to traders on the street. His presence was a sign of hope for many of the traders who worried that their chance of successfully opposing the relocation plan was dwindling. In both the meeting and on the street, PDI-P representatives emphasized their desire to support the "little people" (rakyat kecil). In early November, the traders of Pethikbumi met with members from PKS, who promised to send people to the street alongside PDI-P's operatives to monitor the activities there. $^{73}$

PDI-P's decision to support the traders was met with skepticism because the motivation of the organization was unknown. Most traders assumed that beneath the veil of promises to help the "little people," there must be other political motivations at play. Eko, one of Pethikbumi's leaders, relayed a rumor he had heard: PDI-P was suddenly concerned with the relocation because one of its leaders had given extensive loans to street vendors on Mangkubumi Street and received at least twenty million rupiah per month (approximately 2,194 USD) in interest. Though never verified, this rumor hints at the distrust that street vendors maintained towards political parties and others who supported them for reasons that were unclear. Even though Pethikbumi members welcomed the support of PDI-P and, later, PKS, they also assumed that these political parties had their own hidden motivations for supporting their cause.

Toni and Marini claimed that their political interests for helping the street vendors for free were rooted in their concern with protecting the interests of the poor and marginalized in the city. Yet, their ability to mobilize the traders and their lack of stated personal interests made them susceptible to suspicions that they had secret connections to other political interests. As a result, both Toni and Marini had to regularly reaffirm that they were not receiving money, land, or other payoffs. Marini, for instance, described to me how a government official had offered her money in order to handle an earlier relocation. She recounted her response: "I said that I was a lawyer and that I had no other interests, so why should I ask for land." She concluded that the official was trying to do two things: he wanted to test her, and he wanted to make her a "silent partner." ${ }^{174}$ By telling stories such as this, Toni and Marini tried to

\footnotetext{
${ }^{73}$ Pethikbumi meeting, November 6, 2011, Yogyakarta.

${ }^{74}$ Marini, interview with the author, December 12, 2007, Yogyakarta.
} 
make their interests transparent to the traders and me, as well as to other members of this network.

The leaders of the traders also had to help clarify their own motivations. In a meeting in November 2007, one of the traders, speaking in front of a large group, said, "And give thanks to the leaders. Here is Marini, and we must give thanks to her because she fights for our livelihoods and does not receive anything." ${ }^{75} \mathrm{I}$ often heard the traders make note of this fact in meetings. In one of our first meetings, the trader Arif said to me, "our movement is pure; there are not any other interests, only the interests of our stomachs. We search for incomes to help our families.."

The PPIP—-the Indonesian Youth Movement for Change-became involved in the relocation because a few Pethikbumi traders who were taking classes at the university knew its members from campus. PPIP was formed in 2000 in Salatiga, Central Java, and became a national organization with regional and city-level leaders. The group was created with the goal of educating the rakyat (the people) to organize themselves to protest the government and to create democracy for the people (demokrasi kerakyatan). ${ }^{77}$ In particular, PPIP strived to increase the consciousness of the masses, and embody its manifesto "revolution is practice" (revolusi adalah praktek). ${ }^{78}$

Totok, a member of PPIP, also represents the professional type of leader involved in this relocation. He was born in Jakarta and started his work in the field of activism in 2000 after he joined the student senate and participated in Basic Leadership Exercises (LDK, Latihan Dasar Kepemimpinan) at the University of Janbadra in Yogyakarta. Through this work, he was introduced to a member of the PPIP. He subsequently joined PPIP's protests and discussions. In 2004, after receiving training from PPIP and specializing in defending people against evictions, Totok was involved in helping street vendors who were being evicted from Selokan Mataram (a street in the region of Sleman in the Yogyakarta province). He was also involved in helping food sellers from Malioboro resist relocation. ${ }^{79}$ During the days, Totok worked as a foreman on a project to build irrigation systems in Wates, just outside of Yogyakarta City. He spent his evenings on the street helping to organize various groups, but if a meeting was important enough he would leave his paid work for these activist efforts.

Totok believed that PPIP was radically different from the professional human rights organizations and NGOs, although he considered them all as part of the prodemocracy stream (golongan prodem). He regularly drew the street vendors' attention to the fact that PPIP was not an NGO but a "mass organization" (Ormas), and that it was important to differentiate between the two. NGOs were paid and had to do what their

\footnotetext{
${ }^{75}$ Pethikbumi Meeting, November 6, 2007, Yogyakarta.

${ }^{76}$ Arif, interview with the author, April 2007, Yogyakarta.

${ }^{77}$ Joko, interview with the author, November 21, 2007, Yogyakarta.

${ }^{78}$ Activists gathered in Yogyakarta in March 2000 to write a political manifesto for the organization and discuss how theories of revolution could be put into practice.

${ }^{79}$ PPIP had been active in helping parking agents negotiate and protest a new government regulation in 2004, and in 2005 it helped the parking agents organize for their rights in the face of a new bus route program. PPIP had a number of different divisions. Some individuals focused on urban issues, while others focused on the urban poor, and another section worked with laborers and farmers.
} 
funders required. ${ }^{80}$ It irked Totok that NGOs would declare that they were independent when, from his perspective, they were still tied to funds. For Totok, PPIP was truly independent because it had no funds and was fully staffed by volunteers. Its members paid their own way, including the cost of gas to attend meetings or protests. Members of PPIP were suspicious of BPHK and the NGO Network because of those groups' relationships with foreign donors and the government, and therefore questioned where their "real" interests resided.

Furthermore, Totok argued that the NGOs were, in fact, not closely familiar with the traders and did not understand the internal politics of Pethikbumi. Totok, unlike the NGO supporters, joined the street vendors' internal nightly meetings, and also came to meet informally with them on the street in the evenings. PPIP was able to provide the anti-relocation street vendors with a network of student activists who were prepared to participate in demonstrations. In the network of organizations, PPIP was the most experienced in holding protests; it obtained the permits and helped organize the logistics of the various protests held over the course of the relocation fight.

Marini also discussed how the differences between BPHK and PPIP made the advocacy process difficult. She described how BPHK did not think the street vendors were ready to fight, while PPIP thought they were. Decisions that were made in a meeting with BPHK were later annulled by PPIP. Marini considered PPIP and BPHK to have different visions and missions. In another relocation conflict, years earlier, BPHK and PPIP were both supporting the traders and the result was the same. Marini said, "Ultimately it was crash and conflict." ${ }^{81}$

Totok went out of his way to also illustrate his lack of political play in the relocation. During an interview he said, "Galang tried to offer me two kiosks, but I did not want them because I am not playing there. I am more interested in helping to mentor, that is it. [ $I^{\prime} \mathrm{m}$ ] not [here] because $\mathrm{I}^{\prime} \mathrm{m}$ interested in politics or conspiracy." ${ }^{82} \mathrm{He}$ declared that PPIP received no money from outside funders and that it merely wanted to support the people. Yet, after the relocation, when his name was listed as receiving a kiosk in the new market, people saw this as evidence that he might have been involved in some backstage play. Similar to that of Toni and Marini, Totok's declaration that he had "no interests" (tidak ada kepentingan) made him all the more subject to suspicion.

\section{Named Interests: The Traditional Tough Guy}

Ahmad was allied with Toni and Marini, and supported the anti-relocation traders. Toni and Marini did not, however, communicate with Ahmad or share his advocacy strategies. Ahmad was the leader of an ethnic organization of twenty thousand people in Central Java. He was of a different generation than Toni and Marini, and had a different style and outlook on the relocation. Rather than being concerned with upholding democracy and transparency, Ahmad believed that one of the most effective ways to get things done in the city was to pose a serious threat to the government. A

\footnotetext{
${ }^{80}$ Interview with PPIP member, November 21, 2007, Yogyakarta.

${ }^{81}$ Marini, interview with the author, December 12, 2007, Yogyakarta.

${ }^{82}$ Totok, interview with the author, November 21, 2007, Yogyakarta.
} 
food seller himself in another area of the city, Ahmad had achieved prominence by virtue of his fighting prowess. He had reportedly stood up to the government at various points, and had won because he was willing to die rather than stand down. In September 2007, Ahmad continued this trend and declared that there would be "commotion" or "tumult" in the city if the government proceeded with the relocation. ${ }^{83}$

Located under a veranda, Ahmad's selling location was strategic and protected from the sun and rain. Besides being the leader of the Madurese organization, he was also known to be a powerful mystic. People went to him if they were sick, and for advice about business, politics, and love. Ahmad was seventy-two years old. He moved to Yogyakarta in 1950 after touring major cities like Semarang, Jakarta, and Surabaya. He sold sate beside a railway station until the location was cleared for a parking lot in the early 1990s. After a fight, the government moved him to a strategic site that was also near a major tourist attraction. Telling the story of his encounter with the government, Ahmad said, "I said that if that tent is taken down, it would be me or him that would die. If I die, I will only leave my food stall. I'm brave." ${ }^{\prime 4}$

For over thirty years as the leader of this ethnic organization for Central Java, Ahmad implemented a policy to ensure that his ethnic group was well behaved, and that ethnic or religious group tensions were controlled in the city. This ethnic organization was started in order to maintain peace and order during the Suharto years. In cases when crime or theft occurred in his neighborhood, Ahmad would be called upon to resolve the issue. He explained,

The government of Yogyakarta respects me. They believe me. As a leader, I have never done anything criminal. In reality, I help the government. Like with thieves. When there are thieves here, I let them know that it is their own problem, and they can stay here, but if they want to work they must search for another area. What they get [what they have stolen], they can bring here, they can eat well, sleep well. That's what I'm like. I am not hard, but give a good solution for them so that we are orderly, safe, and there is no problem. The government thus believes me and I often help. But for this problem, I will not help the government. I will help the children [anak-anak]. ${ }^{85}$

Ahmad was part of the earlier generation of tough-guy types who tried to curb and control violence in the city, but also used violence to maintain their own power. In this statement, Ahmad tried to portray himself not as a criminal but as an appendage of the government, because he helped it control criminality in the city.

An interesting twist in the relocation story occurred when Ahmad arrived at a latenight meeting with Pethikbumi and municipal government officials. One of the government officials on the relocation team, Galang, was a member of Ahmad's ethnic organization, so Ahmad was his leader and senior in the ethnic organization. The street traders from Pethikbumi who planned for this surprise encounter laughed when

\footnotetext{
${ }^{83}$ Ahmad, interview with the author, September 18, 2007.

${ }^{84}$ Ibid.

${ }^{85}$ It is common for elders or people in positions of authority to refer to their supporters as their anak buah, or subordinates. Ahmad referred to them as his children, situating them as kin and placing their wellbeing under his jurisdiction.
} 
retelling the story of how Galang immediately stood up when Ahmad arrived, kissed his hand, and bowed lower than usual. The dynamic suddenly shifted in the meeting when Galang could no longer give his commitment exclusively to the government but also had to respect his ethnic leader. Ahmad announced that, in his opinion, the vendors were successful on Mangkubumi Street and there was no reason to move them. "My children here are refusing to move," he said. Galang was forced to respond. He said that if Pethibkumi continued to refuse he would not inhibit them. For Galang to make this shift was significant. Besides being a bureaucrat, Galang was also a community leader (tokoh masyarakat). He was involved in the student movement during reformasi, but more recently had come to act as a religious leader (kyai) and ran a pesantren (a religious school) in Sleman. From the time of this meeting, Ahmad asked and expected Galang to help Pethikbumi resist the relocation in any way possible.

In our discussion a couple of days after the meeting, Ahmad explained his position with the government regarding the relocation:

When I was asked to help by an official from the government, I said that I couldn't help. I wanted to help the street vendors on Mangkubumi because there are some people from [my region] involved. I did not agree. In reality, the mayor should have arranged them [on the street] like Malioboro. I have already spoken this way. I will help those children. The government asked me [to help it], but I didn't want to. Why? Because I and [the street vendors] are both the small people. ${ }^{86}$

Ahmad represents an old type of broker. He posed a threat to the government because he was ready to initiate violence and cause tumult. Yet the government relied on him, at the same time, to prevent crime and uphold peace in the city. Unlike BPHK or the NGO Network, Ahmad was less concerned about democracy, and saw the threat of violence as necessary to achieving results with the state. In the post-Suharto era, Ahmad has retained recognition and clout based on his undiminished fighting prowess, but since the collapse of the New Order he is less content with being directed by vertical patrons. Similar to the gang members, and vigilantes whom Ian Wilson has described, Ahmad was concerned with "stak[ing] territorial claims based upon communal identities, populist rights claims of marginalized social groups and critiques of the state..${ }^{\prime 87}$ He was explicit about his politics, and as a result few of the traders, NGOs, or others questioned his connections and motivations with regard to this relocation. Ahmad was not suspected of backstage negotiations because his political interests could be clearly mapped. Ahmad also stayed below the radar, never appearing in newspapers.

\footnotetext{
${ }^{86}$ This was not the first time Ahmad had helped street traders or others in the city settle disputes. Several years earlier, he had supported street vendors who were trading in front of a major monument on Malioboro Street. He assisted them in searching for a new selling location that would be as busy and potentially rewarding as the old.

${ }^{87}$ Wilson, "Testing the Boundaries of the State," p. 293.
} 


\section{A Less Suspicious Agent: The Hybrid Leader}

Djoko worked closely with the mayor to support the relocation plan. He was involved in distributing money and promises, but aroused less suspicion than Toni and Marini, despite the fact that they had no such connections and asserted they had "no interests." Djoko was the director of Indonesia Law Monitoring Alliance (ILMA). During the initial fortnight of my research, I was not aware of Djoko's involvement in the relocation. None of the street vendors had mentioned him to me, and he was not visible on the street. I learned of him when I was told that I was not allowed to attend the pro-relocation vendors' meetings because Djoko did not want foreign involvement. Uncertain of how to proceed, I asked a close informant, Rusdi, for advice. I was surprised to learn that Rusdi, the leader of the parking organization of Yogyakarta since 2001, was a close friend of Djoko's. They had both been part of the mayor's "success team" in the last election.

Several days later Rusdi brought me to Djoko's office, tucked away in a neighborhood near the Sultan's Palace. Rusdi explained to Djoko that he knew me well, and that I could be trusted. After I described my research and we had a lighthearted conversation, Djoko called the mayor (who was in China at the time) and asked him whether it would be permissible for me to conduct research on the street vendor relocation project. After the mayor gave his approval, Djoko invited me to his office again with my Indonesian Institute of Sciences (LIPI, Lembaga Ilmu Pengetahuan Indonesia) research permit so he could give me an "official" permit of his own. With this two-page legal document in hand, I was "free" to conduct my research. Although Djoko was relatively new on the scene (he had only started to support the vendors when I began my research on this group), he had considerable power over the group of street vendors who supported the relocation, as their political intermediary to the mayor.

With Djoko's help, the Independent street vendors were drawn into relation with an expansive political network to aid them in supporting the relocation. Djoko approached the traders in April 2007 and offered to provide them with his legal services. He promised to help them obtain the best possible memorandum of understanding (MOU) with the municipal government, which would protect their rights in the new marketplace.

Since 2002, Djoko had acted to negotiate terms with the government for traders from the neighborhoods of Beringharjo, Sriwedani, and Giwangan in Yogyakarta. He usually worked to guide groups of street vendors to accept government-organized relocations, but also ensured that the mayor heard their concerns directly. For instance, Djoko invited me to attend a meeting with a group of street vendors whom he was helping to receive tents that had been promised by the government months earlier. In the case of the Independent group, he would work with lower level government officials, but would often-to their discomfort-go above them to speak directly with the mayor. The street vendors would meet with the relocation team, composed of a series of government officials from various departments, but if they had any concerns Djoko could relay them personally to the mayor.

Djoko was born in 1966. He received a law degree from Universitas Islam Indonesia, but sold his house in 2001 and used the proceeds to create a human rights 
NGO that provided criminal suspects with legal representation. His organization was concerned with ensuring that no witness faced intimidation, violence, or torture. "Often a witness is eventually forced to become suspect because of his ignorance of the law," he explained in one of his many newspaper articles. Djoko wrote regularly in the newspaper about human rights and the protection of thugs against unfair legal treatment. In one article, he argued that any police action against alleged preman must uphold Human Rights (Hak Asasi Manusia, or HAM), and that the police should not arrest someone based on the assumption that he or she is a thug. ${ }^{88}$ Some of the other NGOs (especially those supporting the anti-relocation street vendors) believed that Djoko was a preman himself, and not a true human rights activist. I concluded that Djoko was not a thug, but was friends with many preman and helped to protect their legal rights.

Djoko described himself to me as a tough (keras) activist during the fall of the New Order; he had been jailed twice. He proudly showed me the tattoos on his arms and told me of his connections with preman throughout the city. He explained that he used to fight against the government but had learned that such resistance achieved little, and it was far more beneficial to work with government officials. He claimed that if he had wanted to "play" politics, he could by now be rich, but instead he wanted to help organize the poor. He wanted to help the "small people" by working as a not-for-profit operative and trusted that he could help improve the quality of life for many of the street vendors.

Despite his claim that money was not important to his work, Djoko was able to mobilize the Independent leaders and keep them loyal to him and to the cause by promising that they would receive first choice in the assignment of kiosks in the new marketplace, as well as five million rupiah (close to 500 USD) for their efforts in organizing the vendors. Djoko was also receiving money to facilitate the relocation. He admitted to me that he received one million rupiah (approximately 100 USD) per month from the mayor for this work. ${ }^{89}$

Many times when I was at Djoko's office, I was surprised to see who arrived to ask for assistance, chat, or return a favor. His clients and friends included government officials, preman, parliament members, police officers, and journalists, among many others. His network included the mayor and members of his "success team," the Islamic PPP, and the Indonesian Anti-Communist Front (FAKI, Front Anti Komunis Indonesia). The wide array of powerful individuals coming in and out of his office indicated the kind of power Djoko himself held. ${ }^{90}$

It was common knowledge among the traders that the PPP was informally supporting the pro-relocation group through Djoko and his organization. Djoko described PPP as an informal group of his friends, saying that they would help each other even though he was not a member of the political party. Totok from PPIP

\footnotetext{
${ }^{88}$ To protect his identity I will not list the title of the newspaper article.

${ }^{89}$ A low-level official makes approximately 100 USD per month.

${ }^{90} \mathrm{I}$ became a symbol of his network as well when he took a picture of me with himself and his co-workers and framed it. It was placed in his office lounge area for all his visitors to see. It suggested that he also had the support of a foreign researcher.
} 
explained to me that Djoko and the municipal government worked with the PPP because the neighborhoods around Mangkubumi Street were allied with their competition, PDI-P. The traders would naturally be supported by PDI-P because the residents in the neighborhoods behind the street (not the shop owners along the main street) benefited economically from the night market; the traders paid them to store their merchandise and many of the young men from the neighborhood worked as parking agents or traders on the street. Thus, according to Totok, the government looked for another party without strong support in that area and chose the PPP. ${ }^{91}$ In particular, the government worked through a preman located in the south part of the city, who was loosely associated with PPP. ${ }^{92}$

Djoko was particularly close with two individuals from PPP, Munir and Wibawa, who were known to control activities on one of the squares near the Sultan's Palace. Munir was Wibawa's father-in-law, and had a long history of helping the government during street vendor relocations. They both supported this plan in a number of ways, including supplying some of their subordinates, preman, to intimidate those who resisted the project on the street. Wibawa also wrote an article in the newspaper in support of the relocation, but rather than revealing his identity as a member of a political party, he signed the article "Observer of street vendor relocation in Yogyakarta City." ${ }^{93}$ Individuals such as Munir and Wibawa helped the government because they hoped to receive benefits in the new marketplace. After the relocation happened, many of their subordinates received kiosks, and others were found maintaining the pay toilets, a lucrative concession.

Djoko is a reformed activist who has taken on a professional status by creating his own registered organization. He has acted as an informal leader for a number of different street seller organizations. His group, the ILMA, had a fair amount of power on the street because he was also connected with the mayor, journalists, PPP, members of the legislature, and a number of preman. Djoko focused less on the economic underpinnings of his organization, but highlighted his strong connection with the mayor. Although he went through legal channels and helped the street vendors draft an MOU with the municipal government, he also had thugs working in the background to ensure that the anti-relocation traders were threatened and understood the potential price of resistance. Although Toni, Marini, and Djoko all identified themselves as advocates for human rights, the fact that Djoko worked for the mayor, funneled money, and promised material benefits to individuals who supported him distinguished him from Toni and Marini.

The traders considered Djoko to be slightly suspicious because of his back-door dealings. He was a subject of rumor and hearsay because it was difficult to trace all of his political connections. Although he claimed to be helping the poor, he bought the

\footnotetext{
${ }^{91}$ Totok, interview with the author, November 21, 2007, Yogyakarta.

${ }^{92}$ Totok, interview with the author, August 1, 2013, Yogyakarta.

${ }^{93}$ Wibawa said that he agreed with the Sultan's support of the relocation because he believed that the street vendors needed legal support and that their economic situation would improve if they became marketplace sellers. He argued that the facts on the ground suggested that 95 percent of the street vendors from the Southern Square, Aseme Gede, and Mangkubumi were ready to move. Pak Wibawa also encouraged Pethikbumi members not to be scared or hesitant to join the relocation. Field notes, October 27, 2007.
} 
support of the street vendor leaders with money and promises of land. He also bribed thugs, Rusdi, and others in his network this way. However, the fact that these exchanges were explicit made him a less suspicious figure to the traders than were the more clearly nonviolent, idealistic activists-at least within his own network. People knew that he was benefiting personally from the relocation, and that his interests could be connected to the mayor and PPP.

\section{The Breakdown of Alliances: Blaming Each Other}

On the Saturday afternoon of November 10, a number of Satpol PP (Satpol Pamong Praja, Public Order police) trucks and officers were visibly on standby near the street, and by Sunday morning they were occupying Mangkubumi Street in posts along the road. At midnight on November 11, large pots were unloaded from a truck and placed along the sidewalk every few meters in order to "beautify" the street and prevent street vendors from conducting business on the sidewalk. The individuals unloading the pots wore helmets and scarves over their faces to hide their identities. Members of Pethikbumi watched from across the street, and a single journalist, who lived in a nearby neighborhood, recorded the event on video. The municipal government had instructed the civil service police force to occupy the street and prevent traders from returning to the location for up to two weeks. According to two Satpol PP officers, there were 150 officers on Mangkubumi Street that night, including sixty Satpol PP officers and ninety Poltabes (Polisi Kota Besar, Large City Police) ${ }^{94} \mathrm{~A}$ banner was also hung on Mangkubumi Street announcing that street vendors were not allowed to sell there. ${ }^{95}$

The following day a blogger wrote: "Usually the clearance of street traders is colored by chaos between the vendors who refuse and the Satpol PP officers, but this has not happened in Yogyakarta. ${ }^{\prime 96}$ Radar Jogja (a local newspaper) reported:

Last night the atmosphere on Mangkubumi Street seemed quiet. There was not one street vendor who laid out his merchandise. [...] What was seen was tens of police officers who guarded the length of the sidewalk. The police, both in complete uniforms and undercover, were spread over many places. Besides that, you could see the Satpol Pamong Praja officers. Like the police, they were spread in a number of spots along the length of Mangkubumi Street. There were also some on alert on the south side of the Tugu intersection. The sidewalk that is usually used for selling was now occupied by a number of police cars and Satpol PP operational vehicles. ${ }^{97}$

\footnotetext{
${ }^{94}$ The Public Order officers are different from the police because they only enforce city bylaws. For instance, Public Order officers are responsible for taking action against illegal street traders, beggars, and pedicab drivers.

95 The banner read: "Sepanjang Jalan P Mangkubumi sisi bara, mulai dari perempatan Tugu sampai pertigaan Jalan Wongosodi Dilarang untuk berjualan Pedagang kaki lima."

${ }^{96}$ Misterpopo, "Penggusuran (Relokasi) PKL ala Pemkot," Angkringan Kang Popo (Blog), November 12, 2007.

97 "Relokasi Tanpa Gejolak: Pasar Pakuncen Ramai Mangkubumi Lengang," Radar Jogja, November 10, 2007.
} 
The breakdown of the anti-relocation team occurred on November 11. On that day, I found members of Pethikbumi gathered on the east side of Mangkubumi Street in front of the Kedaulatan Rakyat newspaper office. With the street guarded by the police and Satpol PP officers, it was not a plausible option for these vendors to continue to sell there, so they had decided to discuss their next steps forward. In the middle of the meeting, Pethikbumi's secretary, Arif, received an urgent text message from BPHK's lawyer, Marini, asking him to come to the Northern Square of the Sultan's Palace (an open field where vendors sell food). Arif was in the middle of leading the meeting, so he sent Iwan, another leader of Pethikbumi. Iwan asked to borrow my camera in case it might be necessary for him to collect evidence. He then jumped on his motorbike and sped to the Northern Square, a couple of miles away.

Upon his arrival, Iwan found Pak Pramana (another leader of Pethikbumi, who had often helped the street vendors negotiate with the police) with the pro-relocation lawyer Djoko and several police officers from Mobil Brigade (Brimob). ${ }^{98}$ Lawyers from BPHK were also on the scene. Iwan was not able to see what was happening. It appeared that a private meeting was going on, but he could only see that his friend Pramana was involved in discussions with Djoko, who was known to be working for the government to support the relocation.

Iwan reappeared on Mangkubumi Street an hour later with Pak Pramana. They said BPHK was accusing Pak Pramana of being involved in a secret meeting with the government at the Northern Square, and BPHK had called Arif to the square to witness Pramana's supposed betrayal of Pethikbumi. Outraged at this accusation, Iwan and Pak Pramana declared they no longer wanted to be associated with BPHK or the NGO Network. "BPHK was involved in some sort of conspiracy with the government," Iwan said. "Why else would they try to turn Pethikbumi members against each other?" It seemed suspicious to him that BPHK had been at the Northern Square at the exact same moment that Pramana and Djoko were meeting "in secret." Pethikbumi could no longer trust that BPHK was looking out for its interests and thus decided to hold an internal meeting. Iwan and Pramana described an incident involving members of BPHK that had occurred a few days earlier. Iwan and Pramana had been sitting at Pramana's cell phone counter at Jogjatronik, the electronics mall. Marini and her husband, Suyitno, came into the mall and went quickly upstairs without stopping to talk to them or even acknowledging them with a wave or a "hello." Iwan and Pramana thought the couple was avoiding them. It seemed like unusual and unexplainable behavior, and it had raised their suspicions that BPHK might be up to something. ${ }^{99}$

Two days after the incident in the Northern Square, the NGO Network publicly announced its decision to withdraw support from Pethikbumi, arguing that the leaders of Pethikbumi were not consistent. "We think it was a problem that on Thursday night, the ninth of November, 2007, some of the leaders of Pethikbumi met directly with the mayor, which reduced the energy of the fight by the Pethikbumi movement because

\footnotetext{
${ }^{98}$ Pramana used to work for Brimbob, but left it. He then entered into the "dark" world of premanism. When he had his first child he decided to leave this world because he needed to make a real and consistent income. He started selling on Mangkubumi Street in 2000 when there were few traders. He did not occupy his kiosk in Kuncen marketplace after the relocation, and in August 2013 was working as a debt collector.

${ }^{99}$ Marini later explained to me that when they came to Jogjatronik, their computer had broken down and they were in a rush to get it fixed. They had not even seen Pramana or Iwan as they were leaving.
} 
the concentration for the struggle was broken up," NGO Network leader Toni was quoted as saying in an article in Kompas, the national newspaper. Toni said that he did not know why the leaders met with the mayor, and that such negotiations violated a decision made by all members of Pethikbumi on November 7 at the parliament building, where they agreed by vote to reject the relocation.

The story told in newspapers was that Pethikbumi's leadership had negotiated on its own without the support of its members. However, the NGO Network had not had a problem with Pethikbumi negotiating with the government until after the incident at the Northern Square on November 11. No one was willing to discuss the events of November 11, however, either directly or in the newspapers; the incident was treated as a private matter.

Pramana, who had attended the supposed "secret" meeting and was accused by BPHK of betraying Pethikbumi, suspected that BPHK had received payments from the mayor and had been involved in some sort of conspiracy with Djoko. Ultimately, the alliance between BPHK and Pethikbumi broke down because many of the street vendors were no longer convinced that BPHK and the NGO Network were acting in their best interests. They were certain that secret payments or political interests had motivated these groups to help them. As one trader described to me:

What is clear is there is suspicion between us. Did someone create this division between BPHK and us, or did the NGOs want to use us? I don't know. There is a question in my heart. Why did BPHK and the NGO Network want to support us so much even though they were not paid? ${ }^{100}$

Pethikbumi's support network fell apart because the vendors could not trust that their supporters were being truthful about their interests. Pramana said that he could not believe that BPHK was not receiving money from the government. He said, "Do you remember how we were meeting with BPHK three or four times a week and they always provided us with food and snacks? Where was the money for these snacks coming from? They must have been receiving money from somewhere." ${ }^{1101}$ Marini of BPHK also reflected on the suspicions, "On Mangkbumi Street the leaders were new; they did not understand the work of BPHK. Maybe that is why the suspicions emerged." ${ }^{102}$ Ironically, the patron-client relationship of Djoko's group allowed for more trust because money and material goods were exchanged, and his interests were not "unnamed."

\section{The Mayor: "Dialoguing" with the People}

Mayor Herry Zudianto of Yogyakarta claimed to listen to "the people," and in this way he invoked memories of the first president of Indonesia, Sukarno. Pak Herry was born in Yogyakarta in 1955. He studied accounting and graduated from Universitas Gadjah Mada (UGM) in 1981. After working as a clerk in a batik shop, he started trading batik and then became a distributor before starting his own batik shop on

\footnotetext{
${ }^{100}$ Interview, December 7, 2007, Yogyakarta.

${ }^{101}$ Pramana, interview with the author, August 2, 2013, Yogyakarta.

${ }^{102}$ Marini, interview with the author, July 16, 2013, Yogyakarta.
} 
Malioboro Street. Herry was considered a prominent businessman in the city. After reformasi he was very active in PAN. In 2001 he was nominated for the position of mayor of Yogyakarta and was elected for a second term in 2006. ${ }^{113}$ As a well-known entrepreneur, he was able to garner the support of many Chinese businesspeople (who also owned shops on Malioboro Street) as well as Muslim groups when he campaigned as a candidate representing PAN. Herry was part of a growing trend, since the fall of Suharto and the advent of reformasi had prompted a number of businesspeople to become increasingly involved in local politics and run for local political offices. ${ }^{104}$

As mayor, Herry was concerned with transforming the bureaucratic culture of Yogyakarta to make it more democratic and transparent. He made himself available and accessible to ordinary citizens through the use of multi-media technology. On a weekly radio show called "Why Mayor" (Walikota Menyapa), citizens could call and ask him questions or raise concerns about the city. Herry also made himself available through text messages, Facebook, and email. ${ }^{\mid / 5}$ As a result of these efforts, in 2005, Herry won an award for his support of e-government, e-leadership, transparency, and accessibility to public services. ${ }^{106}$

Despite his purported accessibility, Herry initially left a number of high-ranking officials responsible for coordinating the relocation of vendors on Mangkubumi Street, and remained involved only from a distance. Ari, the head of the Office of Industry and Trade, and Galang, the head of the Marketplace Office, had worked together previously in "successfully" relocating traders. ${ }^{107}$ In addition to these two, Herry relied on Djoko to organize and remain close to the pro-relocation traders. The Pethikbumi traders criticized the mayor for not being available to them, because on numerous occasions they asked to meet with Herry but were met by the vice-mayor or lowerlevel officials. During a protest on September 12, 2007, Pethikbumi traders and their supporters marched to the office of the mayor and demanded to meet immediately with Herry himself.

Although Herry was inaccessible early on, he met with Pethikbumi traders on several occasions as the relocation deadline approached. The mayor was aware that many street vendors were skeptical and distrusting of the government, and in an interview he described his strategies for trying to connect with the street vendors so they would not see him as "above" them. He said:

103 "Herry Zudianto: For the Good of Yogyakarta," The Jakarta Post, October 28, 2010, http: / / www.the jakartapost.com/news/2010/10/28/ herry-zudianto-for-good-yogyakarta.html, accessed August 26, 2013.

${ }^{104}$ See Vedi R. Hadiz, ed., "A Political Sociology of Local Elites," in Localising Power in Post-Authoritarian Indonesia: A Southeast Asian Perspective (Stanford, CA: Stanford University Press, 2004), p. 113.

105 "Herry Zudianto: For the Good of Yogyakarta."

106 "Kota Jogja Best of the Best E Government," Pemerintah Kota Jogjakarta, October 26, 2007, http: / / www. jogjakota.go.id/index/extra.detail/ 1331/Kota-jogja-best-of-the-best-e-government.html, accessed August 26, 2013.

${ }^{107}$ The government officials and traders similarly talked of Ari's skill in "talking well" (cara omongnya bagus). According to a number of people, he had the ability to convince people to join the relocation because of his soothing and calm approach to the matter. In contrast, Galang was known for his ability to interpret and intervene in the politics. He had a wide network of relations across the city because he ran his own pesantren (Islamic boarding school) in Sleman. 
We socialized with their language. Not with the language of bureaucracy. The meetings were not held in the offices, but at the food stalls. If I spoke with bureaucratic language, there would be no connection. And we went through the informal leaders. If an informal leader believes [our message], then it is even better. Like with the relocation of Sriwedani, ${ }^{108}$ I brought [the informal leaders] to the [new] marketplace. As a result, they were convinced that I was not far from them, that I was easy to reach. I use the Javanese philosophy witing tresno jalaran soko kulino. This means that love has grown through familiar or frequent communication. I'm always thinking, how can I increase the communities' love towards me? For instance, with street vendors, I often talk and hang out with them. They do not feel distant [from me]. I invite them to my private home. There is no need to focus on the problem. If they want to oppose, then they do not feel good. If there is a conflict I never invite them to my office. ${ }^{109}$

The Indonesian state has often been viewed as having a "powerful unity." ${ }^{110} \mathrm{~A}$ closer examination of the statements by Herry, however, reveals that he worked through informal leaders, who act as "micro-level machines" of the state. ${ }^{111}$ Similar to New Order officials, Herry relied on "informal" deputies to get things done. Yet, when the mayor was unable to negotiate successfully through these informal leaders, he had to present himself as personally accessible and attentive. He spent time with and spoke to the traders in their own language. In other words, Herry had to break down the New Order myth that the state stands above society. ${ }^{112}$ When I asked him about the involvement of the NGOs, he responded that he competed with these organizations in his efforts to win over the street vendors:

I must compete with [the NGOs]. For instance, during the street trader relocation there were some NGOs that became involved. They organized dialogues with the street vendors. I did not directly confront them. Because if there is confrontation, there will not be a resolution to the problem. At the end, the NGOs decided to leave [cease their support of] the street vendors because they were close to me. The street vendors defended by the NGOs did agree to a deal with me. And they came to my home without letting the NGOs know. Because I said to them, the NGOs say they will help you, but will they have full responsibility for your livelihood? Yes, please go ahead and compare the promise I have made you with the promise made by the NGOs, which one is more logical? If [the promise] is not realized, is it easier to prosecute the NGOs or me? So I influenced them by asking, which is more rational? It was like selling a product.

\footnotetext{
${ }^{108}$ Sriwedani refers to a location favored by fruit sellers in an area called Shopping in Yogyakarta. In 2000, the street vendors were moved from Sriwedani to new marketplaces called Giwangan and Pelem Gurih on the outskirts of the city. Their incomes dropped significantly, so in 2002 many of the vendors returned to their original selling locations at the shopping center and to Sriwedani Road and the surrounding area. These street vendors were relocated again in 2004 in order to create a children's educational center called Taman Pintar in the neighborhood.

${ }^{109}$ Herry Zudianto, interview with the author, June 2008, Yogyakarta.

${ }^{110}$ Joshua Barker, "Vigilantes and the State," Social Analysis 50,1 (2006): 203-7.

${ }^{111}$ See ibid., p. 207.

${ }^{112}$ See Timothy Mitchell, "The Limits of the State: Beyond Statist Approaches and their Critics," The American Political Science Review 85,1 (March 1991): 77-96.
} 
As different types of leaders appeared on the scene who did not act as part of the state apparatus, the state had to find new ways to assert itself as a powerful competitor among these groups. Herry, as illustrated in the interview, viewed himself as being in direct competition with the NGOs, but rather than directly attacking the NGOs, he sought to convince the traders that he would be a better patron. In this case, Herry established an image for himself that corresponds to the typical image of NGOs: he defined himself in opposition to the inaccessible and corrupt $\mathrm{New}$ Order state. $\mathrm{He}$ presented the state not as an entity ruling from above, but as part of the informal citylevel machine.

Shortly after the oppositional movement had broken down, Herry made a statement, reported in Jogja Kota, that situated the NGOs as leading the anti-relocation street vendors astray. He stated:

The mayor feels sympathy. In reality, there are some street vendors who are straight, they wish and want to believe their leader; they respect the leader because all leaders will bring good, but [they got sidetracked] because they are influenced from here and there with exaggerated promises. But the mayor believes that Allah will hear the prayers that are sent by all of you. ${ }^{113}$

In this and similar statements after the relocation, the mayor and his allies situated the street vendors as victims of improper patrons. The mayor, other government officials, and parliamentarians expressed their annoyance that these supposedly self-interested outsiders were manipulating the "uneducated" street vendors. The street vendors, as non-agents, could be forgiven and incorporated back in their rightful place as clients of the state. The NGOs were the ones to be distrusted and closely watched. The mayor was thus able to argue that his network was looking out for the small people, while these other actors were pursuing their own interests, although these interests were never named. ${ }^{114}$ By using the language of the New Order, the mayor undermined the authority of the NGOs by implying that they were deceptive. He played on the lingering fear and suspicion from the New Order era. While Herry rejected the New Order model of the state as an inaccessible organization, he simultaneously drew on discourses of the New Order era to question the legitimacy of non-state groups. Although it is true rumors circulated among the actors, and they accused each other of having unnamed interests in the months prior to the collapse of their resistance movement, the government became the most prominent source of this rumor by circulating it in the newspaper.

In 2010, Herry received the Bung Hatta Anti-Corruption Award (BHACA). According to the Jakarta Post, "the awards honor public servants for their integrity and leadership in creating transparency in their respective administration." ${ }^{115}$ Although Herry is most famous for creating a one-stop licensing center for investors, making

113 "Walikota Berharap Pasar Klithikan Membawa Berkah," Government of Yogyakarta, November 13, 2007, http: / / www.jogjakota.go.id/index / extra.detail / 1694/ walikota-berharap-pasarklithikan-membawaberkah.html, accessed August 26, 2013.

${ }^{114}$ Toni, the leader of the NGO Network, commented on how serious the municipal government had become in publishing and marketing and ensuring they were upholding a positive image.

115 "Herry Zudianto: For the Good of Yogyakarta." 
Yogyakarta "the country's most investor-friendly city," he also received recognition for his successful efforts to relocate street vendors. The article describes those efforts:

By creating a dialogue with street vendors, he was able to relocate hundreds of them to a newly built market that was later named Pasar Klithikan, or market for second-hand goods, a few years ago. [...]

So what is his recipe for success? "I like listening to many people," Herry said. ${ }^{116}$

Herry represents both a new and old type of leader in Indonesia. He is "new" in the sense that he desires to listen not to "the people" but to "many people." Following the recent rhetoric on democracy in Indonesia, he represents a new generation of leaders who tap into and trade on the symbolic capital of the concept of "dialogue."117 Yet he is an "old" type of leader in that, similar to Sukarno, Herry claims to be close to the people. ${ }^{118}$ Like the representatives of NGOs, Herry can talk to the people, inspire them, and convince them that he can help them. His constituents' general lack of faith in the government has caused Herry to present himself as an accessible leader, a bapak like Sukarno. ${ }^{119}$

In a book published in 2008 , Herry proudly describes the street vendor relocation as an example of dialogue (contoh dialog):

There are different opinions among the community and the mass media, pro and contra, regarding the ideas and the local government policies to relocate traders who sell used merchandise [klithikan]. Yet, those who have the greatest interests at stake are the klithikan vendors. They should be made partners in the dialogue, participate in the search for a solution despite the different opinions and interests related to the relocation policies. As the mayor, I invited them to meet in my private house, to sit together and dialogue informally from 9:00 PM to 3:00 AM. Each side expressed its attitude, reasons, and hopes, and also stated their claims against the other group. Both sides agreed to listen to each other and were willing to find common ground to solve the problem together. ${ }^{120}$

Herry did not, however, alter his plan significantly based on the requests of the anti-relocation traders. He did not compromise his plan in any real way in response to the protests or suggestions from the anti-relocation forces. The relocation was postponed by two weeks because of the resistance, but in the end the anti-relocation traders, weakened and suspicious of each other, agreed to the relocation. The government gave them kiosks at the back of the marketplace, a location where few customers visited. Most of the anti-relocation traders had to rent kiosks in another section of the marketplace or return to the street to make ends meet. Although the

\footnotetext{
${ }^{116}$ Ibid.

${ }^{117}$ In a book authored by Herry Zudianto, he describes his communication with the street vendors as an example of a dialogue between the government and the community, undertaken in order to resolve a problem. Herry Zudianto, Kekuasaan Sebagai Wakaf Politik: Manajemen Yogyakarta Kota Multikultur (Yogyakarta: Penerbit Kanisius, 2008), p. 17.

${ }^{118}$ Siegel, A New Criminal Type in Jakarta, p. 26.

${ }^{119}$ During a field trip in August 2013, the marketplace traders in Kuncen described Herry Zudianto's style as similar to the much-celebrated Joko Widodo, Governor of Jakarta, and formerly Mayor of Surakarta.

${ }^{120}$ Zudianto, Kekuasaan Sebagai Wakaf Politik, p. 16.
} 
mayor presented himself as a leader who listened to the people, he pushed ahead with the project he had helped develop and was determined to implement.

\section{Conclusion}

The growing importance of the informal economy and blossoming range of organizations in the post-Suharto period have led to a different urban landscape in Yogyakarta City. An examination of the biographies and involvement of different informal leaders in this case involving the relocation of street vendors presents us with a complicated picture of how informal leaders function in the post-Suharto era. From BPHK, PPIP, and NGO Network, we learn that professional human rights advocates are taking up important positions as informal leaders in Indonesia. Their leadership is based on operating through formal and legal channels, but, because, in this case, no money was visibly exchanged nor were their political interests clear, their assistance was met with suspicions of backstage dealings. The unclear and incomplete information about the intentions of these actors propelled the vendors to speculate about their interests. The existence of organizations willing to help without receiving economic and political payoffs was a disjuncture from the past and therefore suspicious.

The story of Ahmad highlights how the tough-guy informal leaders of the past still remain important actors on the political scene today. Ahmad has maintained his position as the leader of an ethnic organization in the post-Suharto era, and he depends on his connections to the police and army and his threats of violence to maintain power. His authority is derived from his capacity to protect the interests of his ethnic group-both poor and rich-in Yogyakarta City. His organization is both professional and connected to the world of violence. Ahmad's relationship to his patron has changed slightly in the reformasi era, however. Like many old-style toughs, he is no longer content with being bossed around by traditional patrons, and speaks in terms of seeking economic equality for his community.

Djoko brokered and mediated relations between the state, the traders, and preman/intelligence. This leader offered the traders access to the state and an ability to navigate the official channels as well as connections and protections that were needed in the informal world. Despite receiving monetary compensation for his involvement in encouraging the relocation, Djoko gained the support of many traders because he offered them help accessing the mayor and drafting a MOU, and his motivations were understood.

Mayor Herry, as the formal leader, highlighted his capacity to listen to and dialogue with the traders. This represents an important shift in politics in the city. The mayor was in competition for the support of traders not only with other political party candidates, but also with NGOs and human rights advocates. To win over his constituents' support, the mayor developed a strategy to make the traders feel close to him. Defining himself in opposition to the inaccessible and corrupt New Order state, he presents the state as part of an informal city-level machine, not a superior and mysterious organization. In a rapidly changing urban context, he promised the traders reliability that the NGOs could not guarantee. 
James Siegel has argued that the witch hunts of 1998-99 occurred because the traditional political structures, such as surveillance and control, had changed. During the New Order, the gaze of the state was so powerful, and the internalization of hierarchy so prominent, that the collapse of these structures shifted the politics of recognition and caused people to consider themselves and others witches. ${ }^{121}$ The continuing accusations that BPHK, the NGO Network, and PPIP might have "unnamed interests" illustrate that new groups are still being interpellated according to the New Order politics of recognition. Despite their attempt to be recognized in new and different ways, these organizations and their representatives were slotted at times into the category of those with "unnamed interests."

Finally, this case study has explored the politics of rumors in the post-Suharto era. During this street vendor relocation, the government publicized rumors about the prodemocracy groups in newspaper articles. Nils Bubandt argues that when the rumors in North Maluku were published in pamphlets, the boundary between official and unofficial discourses became blurred. ${ }^{122}$ In a similar fashion, the lines between official and unofficial discourses were blurred when rumors about Pethikbumi's supporters appeared in the news. ${ }^{123}$ In this case, rather than leaving the pro-democracy groups to author rumors about each other, the mayor positioned himself as the authoritative source of rumors about these groups in the local newspaper. Yet even though these rumors were reported and documented, they did not become the final word on the event. The accused, in this case the NGOs, responded with other versions of events. In this regard, the newspapers become forums for competing conspiracy theories, offering multiple possible versions of events without ever reaching a point of clarity. What is rendered visible more than anything is that urban politics is marked by distrust and paranoia, and a belief in secret political machinations.

\footnotetext{
${ }^{121}$ James T. Siegel, Naming the Witch (Stanford, CA: Stanford University Press, 2006), p. 190.

122 See Bubandt, "Rumors, Pamphlets, and the Politics of Paranoia in Indonesia," p. 795.

${ }^{123}$ See ibid., p. 793.
} 